\title{
Effect of Organic Manures on Antioxidant Activity and Essential Oil Composition of Artemisia annua cv. CIM Arogya
}

\author{
Monika Yashpal Sajwan ${ }^{1 *}$, Dhruv Mishra ${ }^{1}$, M. S. Negi ${ }^{2}$ and P. S. Bisht ${ }^{1}$ \\ ${ }^{1}$ Department of Biological Sciences, College of Basic Science \& Humanities, \\ GBPUA\&T Pantnagar, India \\ ${ }^{2}$ Department of Agronomy, College of Agriculture, GBPUA\&T Pantnagar, Uttarakhand, India \\ *Corresponding author
}

\section{A B S T R A C T}

Keywords

Artemisia annua,

Organic manure,

Farm yard manure,

Poultry manure,

Essential oil

Article Info

Accepted:

25 September 2020

Available Online:

10 October 2020
Organic manure affect the essential oil composition of the flower of Artemisia annua cv. CIM Arogya, growing in Teari region of Uttarakhand, India, along with its antioxidant activity, is reported in the present study. More than sixty compounds were identified, representing $97.5 \%$ of the total oil. The major constituents of the oil were Eucalyptol (1-8 Cineol), Camphor and (3E, 5E)-2, 6- Dimethylcota-3, 5, 7 trien-2-ol in all treatments except T3 (1, 5-Heptadien-4-one, 3,3,6-trimethyl-). Content (\%) of bioactive compounds affect by organic manure. Isolated essential oil was tested for antioxidant activity with DPPH radical, exhibiting promising antioxidant profile.

\section{Introduction}

Artemisia annua L. belonging to the family Asteraceae, is a fragrant annual herb. The genus Artemisia contains more than 400 species, and distributed mainly in the Northern Hemisphere, especially in Asia, Europe and North America (Pellicer et al., 2006; Nibret \& Wink 2010). This genus is represented by 32 species in India (Hajra et al., 1995). Many species of the genus Artemisia are used in the folk and traditional medicine and also used as spices, and for alcoholic drinks (Baser \& Buchbauer 2010). Plant commonly named Sweet Annie, Sweet Wormwood Annie, Sweet Sagewort, Annual Wormwood or Qinghaosu. In Uttarakhand commonly known as "Paanti". In Chinese traditional medicine use of this plant was recorded before $168 \mathrm{BC}$.

In 1972, artemisinin the active crystalline constituent was isolated from the aerial portions of the plant. Artemisinin is a sesquiterpene lactone which have antimalarial properties (Klayman, 1985). It is the only 
commercial source of artemisinin (Ferreira et al., 2013), a potent antimalarial drug (Woerdenbag et al., 1993; Dhingra et al., 2000; Bhakuni et al., 2002; Caniato \& Puricelli 2003). Since then A. annua has become one of the most extensively investigated plants in recent years. Besides its antimalarial activity (Bhakuni et al., 2002) A. апnиa also shows several biological activities such as, anti-inflammatory, anti-oxidant, antipyretic (Huang et al., 1993), anticancer (Zheng, 1994), antifungal (Liu et al., 2001), antiulcerogenic (Foglio et al., 2001), antiparasitic (Kim et al., 2002), and cytotoxic (Nibret and Wink, 2010) activities.

The essential oil composition of A. апnиa plant has been studied thoroughly and hundreds of bioactive compounds have been identified up to date (Brown, 2010). Artemisia ketone, Camphor, and 1, 8-cineole and germacrene D, are usually found as the main bioactive compounds (Ahmad and Mishra, 1994; Tellez et al., 1999; Malik et al., 2009; Brown, 2010). This essential oil is used in the production of perfumes and cosmetics (Nedkov \& Attanassovo 2004).

It is generally accepted that variability of chemical composition of essential oil of $A$. апnиa depends on plant development stage and geographical origin (Verma et al., 2011; Lenardis et al., 2011; Bhakuni et al., 2002; Brown, 2010; Holm et al., 1998). Thus, there is still a considerable research interest in the assay of biological properties and/or composition of essential oil of A. annua from different geographical origin. In the present work, we investigated that effect of treatment on essential oil content and composition of $A$. annua $c v$. CIM Arogya cultivated in Terai region of Uttarakhand. CIM Arogya is the cultivar variety of $A$. annua developed by Central institute of Aromatic and Medicinal Plants (CIMAP), Lucknow. In addition, the aim of this study was to determine the antioxidant activity of the isolated essential oil.

\section{Materials and Methods}

\section{Field trials}

Field trials of the present study were carried out at the experimental field of G. B. PANT University, Uttarakhand, India, foot hills of Himalayas at $29^{\circ}$ North latitude and $79.5^{\circ}$ East latitude and the altitude of 243.83 meter above mean sea level in the year 2017-2018 and 2018-2019. The soil of the experimental field was course in texture having $\mathrm{pH}$ 7.1, electrical conductivity $0.11 \mathrm{ds} \mathrm{m}-1$, nitrogen $281.35 \mathrm{~kg} \mathrm{ha}-1$, phosphorus $29.23 \mathrm{~kg}$ ha-1 and potash $309.34 \mathrm{~kg}$ ha-1.

\section{Sowing and transplantation}

Seeds of A. annua $c v$. CIM Arogya collected from the central institute of Medicinal and Aromatic Plant Lucknow, India were sown in $4 \mathrm{~m} \times 1 \mathrm{~m}$ nursery bed in the month of December. Three-month-old seedlings were then transplanted into the field. The plot size was $34.20 \mathrm{~m}^{2}(5.70 \mathrm{~m} \times 6 \mathrm{~m})$, row to row distance of $50 \mathrm{~cm}$ and plant to plant distance of $45 \mathrm{~cm}$. The plants were irrigated in a week till the requirement.

Treatments: T1: Control (without manure), T2: 20 ton ha $^{-1}$ Farm yard manure, T3: 10 ton ha $^{-1}$ Vermicompost, T4: 10 ton ha $^{-1}$ Poultry manure, T5: 10 ton $\mathrm{ha}^{-1}$ Farm yard manure +5 ton ha $^{-1}$ Vermicompost +5 ton ha ${ }^{-1}$ Poultry manure, T6: Inorganic manure (NPK)

Urea, diammonium phosphate, murate of potash, farm yard manure, vermicompost and poultry were used as the source of nitrogen, phosphorus, potassium, and organic manure, respectively. Phosphorus and potassium fertilizers $(50 \mathrm{~kg} \mathrm{ha}-1$ each) were applied at the time of transplantation, while nitrogen 
fertilizer $150 \mathrm{~kg}$ ha-1 were applied in four equal splits, one at the time of transplantation and 2nd at bolting stage, respectively. Organic manure was also applied at the time of transplantation.

The experimental procedure was arranged in a completely randomized block design with three replicates of each treatment. The plants were harvested at full flowering stage.

\section{Essential oil extraction}

Fresh flowers of A. апnиа $c v$. CIM Arogya was collected to extraction of essential oil via hydro-distillation method. $200 \mathrm{gm}$ of flowers was subjected to Clevenger-type apparatus for $3 \mathrm{~h}$ in $500 \mathrm{ml}$ water. The resultant data (\%) were calculated as volume of essential oils per $200 \mathrm{gm}$ of plant fresh weight basis. The oil was dried over anhydrous sodium sulphate and stored in refrigerator at $4{ }^{\circ} \mathrm{C}$ till analysis.

\section{Gas chromatography- Mass spectrometry (GC-MS)}

GC-MS analysis of essential oil of different treatments (Organic manures and combination of organic manure) was performed by using GC-MS QP2010 Plus (Gas Chromatograph Mass spectrometer, SHIMADZU, USA.) with Rxi ®-5Sil MS capillary GC column (5\% phenyl 95\% dimethyl polysiloxane) with dimension: $30 \mathrm{mts}$, ID: $0.25 \mathrm{~mm}$ and $\mathrm{df}$ : $0.25 \mu \mathrm{m}$. Flow rate of mobile phase (helium as a carrier gas) was set at $1.21 \mathrm{ml} / \mathrm{min}$. In the gas chromatography part, temperature programme (oven temperature) was $80^{\circ} \mathrm{C}$ raised to $250^{\circ} \mathrm{C}$ at $5^{\circ} \mathrm{C} / \mathrm{min}$ and injected with $1 \mu 1$ volume.

\section{Antioxidant activity}

DPPH Free radical scavenging activity was evaluated by measuring the scavenging activity of the Flower essential oil of $A$. аппиа cv. CIM Arogya on stable 2, 2-diphenyl-1picryl hydrazyl radical (DPPH). A $0.04 \%$ solution of DPPH in methanol was prepared in methanol. Various concentrations (0.2-1.0 $\mathrm{mg} / \mathrm{mL})$ were added to $1.0 \mathrm{~mL}(0.04 \% \mathrm{DPPH})$ and final volume was made to $3.0 \mathrm{~mL}$ with methanol. The mixture was shaken thoroughly and incubate at room temperature for 30 minutes. After incubation, absorbance was measured at $517 \mathrm{~nm}$ on a UV-visible spectrophotometer. The decrease in the absorbance indicates an increase in DPPHradical scavenging activity.

DPPH radical scavenging $(\%)=\left[\left(\mathrm{A}_{\mathrm{t}}-\mathrm{A}_{0}\right)\right] \times$ 100

Where $A_{t}$ is the absorbance value of the tested sample and $A_{0}$ is the absorbance value of blank sample, in particular time. L-Ascorbic acid served as positive control. The experiment was done in triplicate and mean values were recorded.

\section{Results and Discussion}

\section{Essential oil content}

The results presented in Table 1 showed that the content of essential oil was increased progressively irrespective of treatments over control. The essential oil content ranges from $0.72 \%$ to $1.2 \%$. The maximum increase in essential oil content was recorded in T6 (1.2\%) followed by T5 (1.08\%), T4 (0.96\%), T3 $(0.88 \%)$, T2 $(0.8 \%)$ over control.

\section{Impact of organic manures on Essential oil composition of A. annua cv CIM Arogya}

The essential oil of A. апnиа $c v$ CIM Arogya was subjected to detailed GC-MS analysis in order to determine the impact of the treatment on volatile constituents. Identification of the essential oil constituents was done on the basis of NIST library, WILEY and mass 
spectrum. The relative percentages of the individual compound were calculated on GC peak area. GC-MS revealed the presence of more than 50 compounds. Major bioactive compounds listed in Table 2.

In T1 (control) 46 bioactive compounds were identified. Camphor (27.89\%), Eucalyptol (25.39\%) and (3E, 5E)-2, 6- Dimethylcota-3, 5,7 trien-2-ol $(5.97 \%)$ were recorded as the main components. In T2 50 compounds were identified of which the first three components are Eucalyptol (31.98\%), Camphor (20.89\%) and (3E, 5E)-2, 6- Dimethylcota-3, 5, 7 trien2-ol (5.30\%). In T3 54 compounds were identified. The most abundant components were Eucalyptol (23.84\%), Camphor $(19.68 \%)$ and 1, 5 Heptadiene-4-one, 3, 3, 6trimethyl (8.90\%).

In T4 51 compounds were identified of which Camphor (26.35\%), Eucalyptol (25.39\%) and (3E, 5E)-2, 6- Dimethylcota-3, 5, 7 trien-2-ol (5.30\%). In T5 47 compounds were identified. The most abundant compound were Eucalyptol (33.20\%), Camphor $(24.89 \%)$ and (3E, 5E)-2, 6- Dimethylcota-3, 5, 7 trien-2-ol $(5.30 \%)$. In T6 50 compounds were identified of which the first three compounds were Eucalyptol (29.80\%), Camphor $(26.00 \%)$ and (3E, 5E)-2, 6- Dimethylcota-3, 5, 7 trien-2-ol $(5.60 \%)$.

Several bioactive compounds in A. annua essential oil have been identified. Significant variations in the content percentage of different bioactive compounds in essential oils from $A$. annua have been recorded. Generally, camphor, 1.8-cineole, artemisia ketone, and germacrene D, artemisia alcohol, were the main bioactive compounds. But, the variation between chemical composition of the essential oil is generally influenced by the fertilizer, harvesting season and the $\mathrm{pH}$ of soils, the geographic location, the choice and stage of drying conditions, subspecies or chemotype, and choice of plant part or extraction method (Bilia et al., 2014).

A. annua plants cultivated in India, camphor (10.5-44.4\%) was found to be the major bioactive compounds of essential oil. Bagchi et al., (2003) revealed that the main components of the essential oil of $A$. апnиa were the artemisia ketone. Jain et al., (2002) reported that artemisia ketone $(52.9 \%), 1.8$ cineole $(8.4 \%)$ and camphor $(6.0 \%)$ were the major components. According to Soylu et al., (2005) chemical composition of A. annua essential oil was rich in camphor (31.7\%), 1.8-cineole $(10.1 \%)$, caryophyllene oxide (7.1\%), $\alpha$-copaene $(3.4 \%)$ and camphene $(3.3 \%)$. A. annua growing wild in Bulgaria, the main component of essential oil was found to be $\alpha$-caryophillene (24.73\%), $\alpha$ cuvebene (13.53\%), artemisia ketone (8.45\%), $\alpha$-selinene $(8.21 \%), \quad \alpha$-copaene (7.24\%), and camphor (3.61\%) (Tzenkova et al., 2010).

Table.1 Impact of organic manure on essential oil content

\begin{tabular}{|c|c|c|}
\hline S.No. & Treatment & Oil content $(\boldsymbol{\%})$ \\
\hline $\mathbf{1}$ & T1 & 0.72 \\
\hline $\mathbf{2}$ & T2 & 0.8 \\
\hline $\mathbf{3}$ & T3 & 0.88 \\
\hline $\mathbf{4}$ & T4 & 0.96 \\
\hline $\mathbf{5}$ & T5 & 1.08 \\
\hline $\mathbf{6}$ & T6 & 1.2 \\
\hline
\end{tabular}


Table.2 Major bio-active compounds found in Essential oil of Artemisia annua cv. CIM Aroogya

\begin{tabular}{|c|c|c|c|c|c|c|c|}
\hline \multirow[t]{2}{*}{ S.No. } & \multirow{2}{*}{ Bioactive compound } & \multicolumn{6}{|c|}{ Treatment } \\
\hline & & $\mathrm{T} 1(\%)$ & $\mathrm{T} 2(\%)$ & $\mathrm{T} 3(\%)$ & $\mathrm{T} 4(\%)$ & $\mathrm{T} 5(\%)$ & $\mathrm{T} 6(\%)$ \\
\hline 1 & Pinene <alpha-> & 2.16 & 1.99 & 1.53 & 2.53 & 2.11 & 2.06 \\
\hline 2 & Camphene & 4.12 & 3.10 & 2.42 & 3.76 & 3.56 & 4.03 \\
\hline 3 & Sabinene & 3.97 & 4.94 & 3.66 & 3.78 & 4.60 & 3.80 \\
\hline 4 & Pinene oxide <beta-> & 0.77 & 0.79 & 0.49 & 0.58 & 0.69 & 0.54 \\
\hline 5 & Myrcene & - & 2.69 & 2.08 & 2.31 & - & 2.68 \\
\hline 6 & Eucalyptol & 25.29 & 31.98 & 23.84 & 25.66 & 33.20 & 29.80 \\
\hline 7 & Terpinene <alpha-> & 0.58 & 0.75 & 0.47 & 0.72 & 0.76 & 0.73 \\
\hline 8 & Terpinene <gamma-> & 1.05 & 1.10 & - & 1.12 & 1.33 & 1.10 \\
\hline 9 & Sabinene hydrate <cis-> & 0.98 & 1.04 & 0.89 & 0.47 & 0.52 & - \\
\hline 10 & $\begin{array}{l}\text { Butyrate <3-methylbutyl-, 2- } \\
\text { methyl-> }\end{array}$ & - & 2.00 & 1.33 & - & - & - \\
\hline 11 & $\begin{array}{l}\text { (3E,5E)-2,6-Dimethylocta- } \\
\text { 3,5,7-trien-2-ol }\end{array}$ & 5.97 & 5.30 & 6.78 & 6.28 & 5.29 & 5.60 \\
\hline 12 & Camphor & 27.89 & 20.89 & 19.68 & 26.35 & 24.11 & 26.00 \\
\hline 13 & $\begin{array}{l}\text { 1,5,7-Octatrien-3-ol, 2,6- } \\
\text { dimethyl- }\end{array}$ & 4.32 & 4.07 & 4.57 & 4.41 & 3.72 & 4.01 \\
\hline 14 & Terpineol <delta $>$ & 1.6 & - & - & 1.25 & - & - \\
\hline 15 & $\begin{array}{l}\text { Cyclohexanemethanol, } \\
\text {.alpha.,,alpha.-dimethyl-4- } \\
\text { methylen }\end{array}$ & - & 1.30 & 1.05 & - & 1.26 & 0.76 \\
\hline 16 & $\begin{array}{l}\text { 3-CYCLOHEXEN-1-OL, 4- } \\
\text { METHYL-1-(1-METHYLET }\end{array}$ & 3.02 & 2.46 & 2.41 & 3.35 & 3.57 & 2.56 \\
\hline 17 & $\begin{array}{l}\text { (+)-ALPHA-TERPINEOL (P- } \\
\text { MENTH-1-EN-8-OL) }\end{array}$ & 1.86 & 1.90 & 2.33 & - & 2.11 & - \\
\hline 18 & Caryophyllene <(E)-> & 2.15 & 1.77 & 1.29 & 1.65 & 1.27 & 1.89 \\
\hline 19 & $\begin{array}{l}\text { CINEOLE <DEHYDRO-1,8-> } \\
\text { DB5-408 }\end{array}$ & - & - & - & - & 2.07 & - \\
\hline 20 & Farnesene $\langle(\mathrm{E})-$, beta- $>$ & 1.83 & 1.68 & 1.77 & 1.54 & 1.69 & 2.29 \\
\hline 21 & $\begin{array}{l}\text { 1,6-CYCLODECADIENE, 1- } \\
\text { METHYL-5-METHYLENE- }\end{array}$ & 2.52 & 2.48 & 1.79 & 2.17 & 1.91 & 2.52 \\
\hline 22 & Cymene <para $>$ & - & - & 5.06 & - & - & - \\
\hline 23 & Terpineol <delta $>$ & 1.61 & - & - & 1.25 & - & - \\
\hline 24 & $\begin{array}{l}\text { 1,5-Heptadien-4-one, 3,3,6- } \\
\text { trimethyl- }\end{array}$ & - & - & 8.90 & - & - & - \\
\hline 25 & $\begin{array}{l}\text { BENZENE,METHYL (1- } \\
\text { METHYLETHYL)- }\end{array}$ & - & - & - & 3.14 & - & - \\
\hline
\end{tabular}

$(-)=$ absent 
Table.3 Impact of manure on DPPH radical scavenging activity (\%)

\begin{tabular}{|c|c|c|c|c|c|c|c|}
\hline \multirow{2}{*}{$\begin{array}{l}\text { Concentration } \\
(\mathrm{mg} / \mathrm{ml})\end{array}$} & \multicolumn{7}{|c|}{ Treatment } \\
\hline & $\mathrm{T} 1$ & $\mathrm{~T} 2$ & T3 & $\mathrm{T} 4$ & T5 & T6 & $\begin{array}{l}\text { L-Ascorbic } \\
\text { Acid }\end{array}$ \\
\hline 0.2 & $50.34 \pm 0.37$ & $54.58 \pm 0.56$ & $58.46 \pm 0.43$ & $61.03 \pm 0.68$ & $65.89 \pm 0.56$ & $52.86 \pm 0.86$ & $85.86 \pm 0.54$ \\
\hline 0.4 & $71.81 \pm 0.98$ & $75.89 \pm 0.56$ & $78.54 \pm 1.31$ & $79.86 \pm 1.17$ & $80.45 \pm 0.65$ & $73.48 \pm 0.41$ & $90.43 \pm 0.27$ \\
\hline 0.6 & $77.37 \pm 1.03$ & $80.38 \pm 1.29$ & $82.31 \pm 1.66$ & $83.33 \pm 1.34$ & $86.34 \pm 0.01$ & $79.69 \pm 1.28$ & $92.42 \pm 0.41$ \\
\hline 0.8 & $84.82 \pm 2.04$ & $86.64 \pm 0.76$ & $87.91 \pm 0.96$ & $88.45 \pm 1.21$ & $91.23 \pm 0.90$ & $86.21 \pm 0.36$ & $94.83 \pm 0.72$ \\
\hline 1.0 & $88.97 \pm 0.09$ & $91.41 \pm 0.43$ & $92.35 \pm 1.09$ & $93.82 \pm 0.64$ & $95.81 \pm 0.57$ & $90.89 \pm 0.10$ & $96.71 \pm 0.65$ \\
\hline
\end{tabular}

Fig.1 Effect of treatment on variation in the major bioactive compounds of A. аппиа $c v$ CIM Arogya

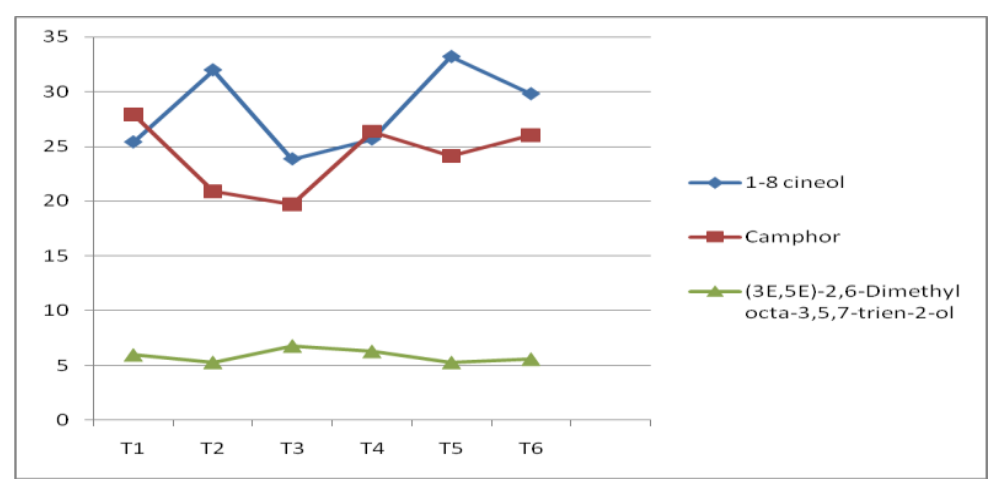

The percentage of bioactive compound in the essential oil of A. апnиa depends on time of harvesting of the plant material (C'avar et al., 2012).Variation between chemical compositions of essential oils from А.аппиа plants harvested in different flowering stage. $\mathrm{Yu}$ et al., (2011) stated that $\beta$-myrcene $(37.71 \%)$, 1.8-cineole $(16.11 \%)$, germacrene D (18.1\%), camphor (15.84\%) and (Z)- $\beta$ farnesene $(9.43 \%)$ were main compounds in the pre-flowering oil; camphor (16.62\%), caryophyllene $\quad(16.27 \%), \quad \beta$-caryophyllene oxide (15.84\%), $\beta$-farnesene (9.05\%) and (-)spathulenol $(7.21 \%)$ were major components in the post flowering oil. Senkal et al., (2014) reported that artemisia ketone $(37.15 \%)$, camphor $(23.80 \%)$ and 1.8 -cineole $(10.39 \%)$ were the main components in Full-flowering oil. Correspondingly, in our study, 1.8cineole, camphor and (3E, 5E)-2, 6Dimethylcota-3, 5, 7 trien-2-ol were the major bioactive compounds. The percentage and chemical composition of essential oils are influenced according to the developmental stages of the plants and by the time of harvest. The vegetative stage of plants, biosynthesis of essential oil bioactive compounds is low. The necessary enzymes for the biosynthesis of some bioactive compounds are not active during the vegetative stage. Thus, the quality of essential oil mostly affected by plant harvest stage (Nurzyńsja-Wierdak 2013; Rodrigues et al., 2013).

\section{Antioxidant Activity}

The antioxidant principle in their interaction depends on oxidative free radicals. The results presented in Table 2. revealed that the free radical scavenging activities of oil were maximum found to be the order of T5 $>$ T3>T4 $>$ T2 $>$ T6 and T1. Statistically significant effect $(\mathrm{P}<0.05)$ of different treatment. 
In general, the antioxidative effectiveness of essential oil depends on the content of phenolic compounds (C'var et al 2012; Hasimi et al 2014). Lopes-Lutz et al., (2008) reported that essential oils obtained from plants belonging to the Artemisia genus are markedly rich in non-phenolic compounds. According to Juteau et al., (2002) the essential oil of A. annua aerial parts, consisting of camphor (44\%), germacrene D $(16 \%)$, trans-pinocarveol (11\%), $\beta$-selinene $(9 \%), \beta$-caryophyllene $(9 \%)$ and artemisia ketone $(3 \%)$, have been weak antioxidant activity. Essential oils of several Artemisia species such as $A$. absinthum, A. cana, $A$. biennis, A. longifolia, A. dracunculus, A. ludoviciana, A. frigida, and A. herba-alba, shows similar results, which are dominant by non-phenolic components (LopesLutz et al., 2008; Mighri et al 2010).

In conclusions our results indicated that the different treatment (organic manures) also affect the percentage, chemical composition and antioxidant activity of essential oil obtained from A. апnиа $c v$ CIM Arogya. The essential oil content was low in T1 $(0.72 \%)$, but rapidly increasing in the other treatment $(0.8 \%, 0.88 \%, 0.96,1.08 \%$ and $1.2 \%$ for $50 \%$ T2, T3, T4, T5 and T6 respectively).

Major bioactive compounds (1.8-cineole (Eucalyptol), camphor and (3E, 5E)-2, 6Dimethylcota-3, 5, 7 trien-2-ol) amounts were varied in different treatments. The essential oils exhibit marked radical-scavenging activity. The highest DPPH activity was recorded in essential oil of plant harvested in T5.

\section{Acknowledgement}

The authors are the highly thankful to Joint director, MRDC Pantnagar, for his kind support during this work.

\section{References}

Ahmad, A., Mishra, L.N., 1994. Terpenoids from Artemisia annua and constituents of its essential oil. Phytochemistry 37 (1), 183-186.

Bagchi G D, Haider F, Dwivedi P D, Singh A \& Naqvi A A (2003). Essential oil constituents of Artemisia annua during different growth periods at monsoon conditions of subtropical North Indian plains. Journal of Essential Oil Research 15(4): 248-250.

Baser K H C \& Buchbauer G (2010). Handbook of essential oils science, technology, and applications. In: G Buchbauer (Ed), Biological Activities of Essential Oils, New York, pp. 235-273.

Bhakuni, R.S., Jain, D.C., Sharma, R.P., 2002. Phytochemistry of Artemisia annua and the development of artemisinin-derived antimalarial agents. In: Wright, C.W. (Ed.), Artemisia. Taylor \& Francis, London, UK, pp. 211-248.

Bhakuni, R.S., Jain, D.C., Sharma, R.P., Kumar, S., 2001. Secondary metabolites of Artemisia annua and their biological activity. Current Science. 80 (1), 35-48.

Bilia, A.R., Santomauro, F., Sacco, C., Bergonzi, M.C. and Donato, R.,2014. Essential oil of Artemisia annua L.: an extraordinary component with numerous antimicrobial properties. Evidence-based complementary and alternative medicine, 2014.

Brown, G.D., 2010. The biosynthesis of artemisinin (Qinghaosu) and the phytochemistry of Artemisia annua L. (Qinghao). Molecules 15 (11), 76037698.

C'avar S, Maksimovi'c M, Vidic D \& Pari'c A (2012). Chemical composition and antioxidant and antimicrobial activity of essential oil of Artemisia annua L. from Bosnia. Industrial Crops and Products 37: 479-485.

Caniato R \& Puricelli L (2003). Natural antimalarial agents (1995-2001). Critical 
Reviews in Plant Sciences 22(1): 79-105.

COŞGE ŞENKAL, B., Kiralan, M. and Yaman, C.,2015. The effect of different harvest stages on chemical composition and antioxidant capacity of essential oil from Artemisia annua L. Journal of Agricultural Sciences.

Dhingra V, Pakki S R \& Narasu M L (2000). Antimicrobial activity of artemisinin and its precursors. Current Science 78(6): 709-713.

Ferreira J F S, Zheljazkov V D \& Gonzaleza J M (2013). Artemisinin concentration and antioxidant capacity of Artemisia annua distillation byproduct. Industrial Crops and Products 41: 294-298.

Foglio, A., Possenti, A., Nogueira, D.C.F., de Carvalho, J.E., 2001. Antiulcerogenic activity of crude ethanol extract and some fractions obtained from aerial parts of Artemisia annua L. Phototherapy Research. 15 (8), 670-675.

Hajra, P.K., Sashtry, A.R.K. and Sanjappa, M. eds., 1995. Fascicles of Flora of India: Leguminosae, Papilionoideae: Tribe, Indigofereae. Bot. Survey of India, Botanic Garden.

Haşimi N, Tolan V, Kızıl S \& Kılınç E (2014). Determination of essential oil composition, antimicrobial and antioxidant properties anise (Pimpinella anisum L.) and cumin (Cuminum cyminum L.) seeds. Tarim Bilimleri Dergisi-Journal of Agricultural Sciences 20 (1): 19-26.

Holm, Y., Laakso, I., Hiltunen, R., Galambosi, B., 1998. Variation in the essential oil composition of Artemisia Artemisia annua annua $\mathrm{L}$. of different origin cultivated in Finland. Flavour and Fragrance Journal. 12 (4), 241-246.

Huang L, Liu J F, Liu L X, Li D F, Zhang Y, Nui H Z, Song H Y \& Zhang C Y (1993). Antipyretic and antiinflammatory effects of L. Zhongguo Zhong Yao Za Zhi 18(1): 44-48.

Huang, L., Liu, J.F., Liu, L.X., Li, D.F., Zhang, Y., Nui, H.Z., Song, H.Y., Zhang, C.Y., 1993. Antipyretic and anti-inflammatory effects of Artemisia annua L. China journal of Chinese Materia Medica. 18 (1), 44-48.

Jain N, Srivastava S K, Aggarwal K K, Kumar S \& Syamasundar K V (2002). Essential oil composition of Artemisia annua L. 'Asha' from the plains of northern India. Journal of Essential Oil Research 14(4): 305-307.

Juteau, F., Masotti, V., Bessière, J.M., Dherbomez, M., Viano, J., 2002. Antibacterial and antioxidant activities of Artemisia annua essential oil. Fitoterapia 73 (6), 532-535.

Kim, J.T., Park, J.Y., Seo, H.S., Oh, H.G., Noh, J.W., Kim, J.H., Kim, D.Y., Youn, H.J., 2002. In vitro antiprotozoal effects of artemisinin on Neospora caninum. Veterinary Parasitology. 103 (1-2), 5363.

Klayman, D.L., 1985. Qinghaosu (artemisinin) an antimalarical drug from China. Science 223, 1049-1055.

Lenardis, A.E., Morvillo, C.M., Gil, A., de la Fuente, E.B., 2011. Arthropod communities related to different mixtures of oil (Glycine max L. Merr.) and essential oil (Artemisia annua L.) crops. Industrial Crops and Products. 34 (2), 1340-1347.

Liu, C.H., Zou, W.X., Lu, H., Tan, R.X., 2001. Antifungal activity of Artemisia annua endophyte cultures against phytopathogenic fungi. Journal of Biotechnology. 88 (3), 277-282.

Lopes-Lutz, D., Alviano, D.S., Alviano, C.S., Kolodziejczyk, P.P., 2008. Screening of chemical composition, antimicrobial and antioxidant activities of Artemisia essential oils. Phytochemistry 69 (8), 1732-1738.

Malik, A.A., Showkat, J.A., Mir, R., Ali, A., Abdin, M.Z., 2009. Influence of chemical and biological treatments on volatile oil composition of Artemisia annua Linn. Industrial Crops and Products. 30 (3), 380-383.

Mighri H, Hajlaoui H, Akrouta A, Najjaa H \& Neffat M (2010). Antimicrobial and antioxidant activities of Artemisia herba- 
alba essential oil cultivated in Tunisian arid zone. Comptes Rendus Chimie 13(3): 380-386.

Nedkov N \& Attanassova M (2004). Essential Oil and Medicinal Crops. Kameja Press, Sofia, Bulgaria.

Nibret, E., Wink, M., 2010. Volatile components of four Ethiopian Artemisia species extracts and their in vitro antitrypanosomal and cytotoxic activities. Phytomedicine 17 (5), 347-36.

Nurzyńska-Wierdak R (2013). Essential oil composition of the coriander (Coriandrum sativum L.) herb depending on the development stage. Acta Agrobotanica 66(1): 53-60.

Pellicer J, Garcia S, Garnatje T, Oriane H, Korobkov A A, Dariimaa S \& Vallès J (2007). Chromosome counts in Asian Artemisia L. (Asteraceae) species: from diploids to the first report of the highest polyploidy in the genus. Botanical Journal of the Linnean Society 153(3): 301-310.

Perazzo, F.F., Carvalho, J.C.T., Carvalho, J.E., Rehder, V.L.G., 2003. Central properties of the essential oil and the crude ethanol extract from aerial parts of Artemisia annua L. Pharmacologcal Research. 48 (5), 497-502.

Rodrigues, L, Póvoa O, Teixeira G, Figueiredo A C, Moldão M, Monteiro A (2013). Trichomes micromorphology and essential oil variation at different developmental stages of cultivated and wild growing Mentha pulegium L. populations from Portugal. Industrial Crops and Products 43: 692-700.

Soylu E M, Yiğitbaş H, Tok F M, Soylu S, Kurt
S, Baysal O \& Kaya A D (2005). Chemical composition and antifungal activity of the essential oil of Artemisia annua L. against foliar and soil-borne fungal pathogens. Zeitschrift für Pflanzenkrankheiten und Pflanzenschutz Journal of Plant Diseases and Protection 112(3): 229-239.

Tellez, M.R., Canel, C., Rimando, A.M., Duke, S.O., 1999. Diferential accumulation of isoprenoids in glanded and glandless Artemisia annua L. Phytochemistry 52 (6), 1035-1040.

Tzenkova R, Kamenarska Z, Draganov A \& Atanassov A (2010). Composition of Artemisia annua essential oil obtained from species growing wild in Bulgaria. Biotechnology \& Biotechnological Equipment 24(2): 1833-1835.

Verma, R. K., Chauhan, A., Verma, R. S., Gupta, A. K., (2011). Influence of planting date on growth, artemisinin yield, seed and oil yield of Artemisia annua L. under temperate climatic conditions. Industrial Crops and Products. 34, 860864.

Yu Z W, Wang B C, Yang F M, Sun Q Y, Yang Z N \& Zhu L C (2011). Chemical composition and antiacetylcholinesterase activity of flower essential oils of Artemisia annua at different flowering stage. Iranian Journal of Pharmaceutical Research 10(2): 265-271.

Zheng, G.Q., 1994. Cytotoxic terpenoids and flavonoids from Artemisia annua. Planta Medica. 60 (1), 54-57.

\section{How to cite this article:}

Monika Yashpal Sajwan, Dhruv Mishra, M. S. Negi and Bisht, P. S. 2020. Effect of Organic Manures on Antioxidant Activity and Essential Oil Composition of Artemisia annua cv. CIM Arogya. Int.J.Curr.Microbiol.App.Sci. 9(10): 3922-3930. doi: https://doi.org/10.20546/ijcmas.2020.910.452 